\title{
Modeling of regional clusters considering sustainable development
}

\author{
Lesia Zaburanna \\ Doctor of economic sciences, professor, \\ professor at department of management \\ named after prof. Zavadskyi Y.S. \\ National university of life and \\ environmental science of Ukraine \\ Kyiv, Ukraine \\ https://orcid.org/0000-0002-3310-125X
}

\author{
Yulia Yarmolenko \\ Ph.D. in Economics, \\ associate professor at department of \\ Marketing \\ Academy of Labour, Social Relations \\ and Tourism \\ Kyiv, Ukraine \\ https://orcid.org/0000-0002-1814-5828 \\ Tetiana Artyukh \\ Ph.D. in Economics, Associate \\ Professor, \\ associate professor at department of \\ management named after prof. \\ Zavadskyi Y.S. \\ National university of life and \\ environmental science of Ukraine \\ Kyiv, Ukraine \\ https://orcid.org/0000-0002-5603-7211
}

\author{
Myroslav Kozak* \\ Ph.D. in Economics, \\ head of department, \\ National Scientific Centre "Institute of \\ Agrarian Economics" \\ Kyiv, Ukraine \\ https://orcid.org/0000-0002-8504-5528
}

\begin{abstract}
Estimation issue of regional sustainable development in Ukraine is studied in the article. Methodical approach that allowed us to rate regions using calculated numbers on indices blocks of resource support, production, social development and ecology state was suggested. This allowed us to compare various components of sustainable development in regions perspective. Three regional clusters were established from the totality of the indices using the method of classification theory; this allows us to devise development scenarios and optimal functioning strategies of regional systems in Ukraine based on sustainable development principle.
\end{abstract}

Keywords-regional development, sustainability, resource support, production, social development, ecology state.

\section{INTRODUCTION}

Current tendencies of economy regionalization and disproportionality of social-economic development of particular regions cause the necessity of state policy regional differentiation. The experience of European countries with developed economy proves extraordinary importance of calculated regional policy when providing sustainable development. Accordingly, the role of regional policy determines particular actuality and value of interregional comparison of social-economic development, economic, nature and resource, demographic and labor potentials of regions as well as defining particular place of every region on the unified national scale. This causes the need to make integral regional estimation of social-economic development level based on specifically formed system of regional statistics indices that mirrors major components and factors of sustainable development in each particular region and provides the possibility of regional comparison based on generalized and detailed features.
The concept of sustainable development spread after publishing the report Our Future [1] prepared by the UN Environment and Development Commission. In 1992 within UN conference in Rio de Janeiro the global issues of sustainable development were defined and Agenda 21 was approved as well as the need of developing indices of sustainable development was established. United Nations General Assemblies in 1997, 2003 and 2009, scientific quorums of progressive world countries were dedicated to issues of sustainable development and its actuality for humanity. Sustainable Development Goals were set at the UN summit in 2015 for the year 2030. But the number of sustainable development issues has not only been unsolved since the time of setting the goals, but it is added with new ones. This in particular is mentioned in the report of Club of Rome [2]. The matter of regional sustainable development is distinguished among all the issues since it is the most complicated one as it requires development of specific indices according to a particular region. Thus, at the opening of II UN High Level Conference on South-South Cooperation the UN President Antonio Guterres stated that the humanity still has plenty of problems fulfilling Agenda 21 for Sustainable Development for the year 2030. In particular, he pointed out the increase of disproportion inside countries as well as among them which undermines trust and boosts the feeling of injustice [3].

Works of many scientists, in particular M. Z. Zhurovskyi [4], V.M. Heiets [5], A.S. Halchynskyi, Khvesyk M.A. [6], Z.V. Herasymchuk [7], were dedicated to the issues of regional sustainable development and making indices for estimating them. Despite profound theoretical-methodical studies and the availability of various methods, the problem of regional sustainable development estimation stays unsolved and requires further research. Insufficiently studied 
is the direction of creating regional clusters considering sustainable development.

The goal of this scientific article is to assess the regional sustainable development in Ukraine and based on it to model regional clusters.

\section{METHODOLOGY}

Methodological approach to assess regional sustainable development consists in distinguishing the system indices under four groups (resource support, production, social development and ecology state), standardization of selected indices that is bringing them to one base (immeasurable values) on condition that correlation between them is saved, calculation of integral index. In order to characterize the selection, such statistic indices were used: variation scope, mean value, average lineal deviation, standard deviation and variation coefficient. Correlation matrix was used to measure interdependence among indices groups. Clusters modeling was done using the algorithm of k-means clustering. Calculation time span made covered 2007-2017.

On the current stage of Ukrainian national economy development, the task to transit to sustainable development of every region and the country as a whole is vital. A complex study of regional aspects of sustainable development includes economic, social and ecological components. Every component refers to a particular group of indices which form a system of indicators. An algorithm of making an integral regional index is a three-stage process according to four-level hierarchical system of indices.

On stage 133 sustainable development indices were selected, they incorporate into four groups:

- $\quad$ resource support;

- production;

- $\quad$ social development;

- ecology state.

The indices included into the study correspond with basic principles of the indices system structure described in the method of State Statistics Service of Ukraine [8], in particular they: correspond with the principles of systematic approach; provide complex approach of regional assessment; provide availability of indices in regions perspective; provide interpretation definiteness of stimulators and destimulators indices of development; transparency, convenience and laconism; authenticity of indices forming sources.

In order to compare regions, only relative indices were used. All the indices were calculated as weighted during seven years - from 2010 to 2016 . A system of indices which consists of four groups and is a basis for building an integral index is formed based on the selection.

The following indices were included to group 1 (resource support):

1) Normative monetary estimation of arable land and set-aside in Ukraine as of January 1, 2017 (a unit Ukrainian hryvnia per hectare);
2) A number of workers per 100 ha of agricultural land (a unit-persons);

3) Conventional livestock in all the categories of agricultural producers per 100 ha of agricultural land;

4) Substantial investment per 1 ha of agricultural land (a unit - Ukrainian hryvnia);

5) Production expenses of agricultural enterprises per 1 ha of agricultural land (a unit - Ukrainian hryvnia);

6) Availability of power facilities of agricultural enterprises per 1 ha of agricultural land (a unit $-\mathrm{kWh}$ );

In order to describe production (group 2) the following activity indices were established:

7) Production of gross output in vegetation per 100 ha of agricultural tillage (a unit - thousands of hryvnias);

8) Production of gross output in livestock raising per 100 ha of agricultural land (a unit - thousands of hryvnias);

9) Production of gross output in livestock raising per 1 conventional head of cattle per100 ha of agricultural land (a unit - thousands of hryvnias);

10) Production of agriculture per one person (a unit Ukrainian hryvnia);

11) Income (receipts) of agricultural enterprises per 1 ha of agricultural land (a unit - Ukrainian hryvnia);

12) Profit of agricultural enterprises per 1 ha of agricultural land (a unit - Ukrainian hryvnia);

13) Profit of agricultural enterprises per 1 worker (a unit - thousands of hryvnias);

14) Expenses recoupment in agricultural enterprises, income (receipts) per one hryvnia of expenses (a unit Ukrainian hryvnia).

Social development (group 3) has such indices established:

15) The level of milk self-providing (a unit - \%);

16) The level of meat self-providing (a unit - \%);

17) The employment level of rural population aged 1570 (a unit - \%);

18) The share of agricultural enterprises workers to economically active population (a unit - \%);

19) Joint resources of one household on the average during a month at a rate per one rural household (a unit Ukrainian hryvnia);

20) Average monthly wage of agricultural enterprises workers and relevant services (a unit - Ukrainian hryvnia);

21) Average age of rural residents (a unit - age);

22) A number of newborns per 1,000 people of existing population;

23) Pre-school institutions accommodating 10,000 persons;

24) Schools accommodating 10,000 persons;

25) Clubs accommodating 10,000 persons.

The following indices are used to describe regional ecology state (group 4):

26) The level of agricultural land plowing (unit - \%);

27) The level of arable land exploitation intensity (unit $-\%)$

28) The share of intensive crops (sunflower, rape and corn, unit $-\%$ ); 
29) The share of land with using of plant protection products by agricultural enterprises (unit - \%);

30) The share of organically manured land square (unit $-\%)$

31) Applying fertilizers per 1 ha of area under crops (unit - tons);

32) Emissions of pollutants into the air from stationary and mobile sources of pollution per square (unit - 1,000 tons);

33) Capital investment and current expenses of protection and rehabilitation of soil, underground and surface waters, per 1 ha of land square (unit - Ukrainian hryvnia).

When forming a general index it's necessary to provide single informational direction of indices. Thus, they are devided into stimulators and destimulators. The connection between a general index and an index-stimulator is direct, the one between an index and an index-destimulator is reverse. Among the selected indices are the average age of rural residents, the level of agricultural land plowing, the level of arable land exploitation intensity, the share of intensive crops, the share of land with using of plant protection products by agricultural enterprises, emissions of pollutants into the air from stationary and mobile sources of pollution per square kilometer are destimulators, as their increasing worsens the resultative sign (rural development index). All other indicators are stimulants. When aggregated into one assessment, destimulators turn into stimulators.

On stage 2 in order to provide comparison, advance standardization of the selected indices was done, that is bringing them to one base (immeasurable values) on condition that correlation between them is saved. The standardization of indices is done according to the formula [9]:

$$
R_{j}=\sum_{i=1}^{n} \frac{x_{\max i}-x_{i j}}{x_{\max i}-x_{\min i}}+\sum_{i=1}^{n} \frac{x_{i j}-x_{\min i}}{x_{\max i}-x_{\min i}}
$$

where $R_{j}$ is a sum of rating assessments of a particular region according to every index which characterize a separate aspect;

$x_{i j}$ is value of index $i$ of region $j$;

$x_{\text {max }}$ is maximum value of index $i$;

$x_{\min i}$ is minimum value of index $i$.

The first part of the formula is used to assess stimulators indices, the second one is used to assess destimulators indices.

Then we establish arithmetic mean value of the sum of regions integral indices according to all the indices which characterize a separate group according to the formula:

$$
R_{c p j}=\frac{R_{j}}{n}
$$

where $R_{c p j}$ is arithmetic mean of integral indices sum of a particular region according to all indices of a particular group;

$n$ is a number of indices according to which assessment by a separate group is done.
On stage 3 according to the results of calculation an integral rating assessment as arithmetic mean value of rating assessment sum of a particular region is done for all groups according to the formula:

$$
\boldsymbol{I}_{j}=\frac{\sum_{i=1}^{m} \boldsymbol{R}_{c p i}}{m}
$$

where $I_{j}$ is arithmetic mean value of rating assessment sum of a particular region for all groups;

$m$ is a number of directions according to which an assessment is done.

\section{RESULTS OF RESEARCH}

With standardized coefficient of every index, a rank of every region and integral rating assessment are granted to integral indices for all rates of every group (Table I).

\begin{tabular}{|c|c|c|c|c|c|}
\hline \multirow[b]{2}{*}{ Region } & \multicolumn{4}{|c|}{$\boldsymbol{R}_{c p j}$} & \multirow{2}{*}{\begin{tabular}{|c} 
Integral \\
rating \\
assessme \\
nt $I_{j}$
\end{tabular}} \\
\hline & $\begin{array}{c}\text { Resource } \\
\text { support }\end{array}$ & Production & $\begin{array}{c}\text { Social } \\
\text { development }\end{array}$ & $\begin{array}{c}\text { Ecology } \\
\text { state }\end{array}$ & \\
\hline Vinnytsia & 0.4696 & 0.5370 & 0.4713 & 0.7544 & 0.5581 \\
\hline Volyn & 0.4200 & 0.6412 & 0.4475 & 0.4073 & 0.4790 \\
\hline $\begin{array}{l}\text { Dnipropetro } \\
\text { vsk }\end{array}$ & 0.6844 & 0.6608 & 0.6186 & 0.7215 & 0.6713 \\
\hline Donetsk & 0.6874 & 0.7349 & 0.6827 & 0.7852 & 0.7225 \\
\hline Zhytomyr & 0.8341 & 0.6036 & 0.4478 & 0.5379 & 0.6059 \\
\hline Zakarpattia & 0.3352 & 0.5420 & 0.6316 & 0.4838 & 0.4981 \\
\hline Zaporizhia & 0.8155 & 0.7176 & 0.6060 & 0.7260 & 0.7163 \\
\hline \begin{tabular}{|l|} 
Ivano- \\
Frankivsk \\
\end{tabular} & 0.1761 & 0.2140 & 0.6094 & 0.4663 & 0.3664 \\
\hline Kyiv & 0.4391 & 0.4969 & 0.5693 & 0.4497 & 0.4887 \\
\hline Kirovohrad & 0.8113 & 0.4704 & 0.5094 & 0.8615 & 0.6631 \\
\hline Luhansk & 0.9485 & 0.7702 & 0.6529 & 0.7397 & 0.7778 \\
\hline Lviv & 0.5458 & 0.4413 & 0.5396 & 0.5672 & 0.5235 \\
\hline Mykolaiv & 0.8911 & 0.5704 & 0.4493 & 0.7644 & 0.6688 \\
\hline Odesa & 0.8250 & 0.7964 & 0.6268 & 0.7112 & 0.7399 \\
\hline Poltava & 0.6496 & 0.3820 & 0.4805 & 0.6466 & 0.5397 \\
\hline Rivne & 0.5991 & 0.6412 & 0.5004 & 0.5023 & 0.5608 \\
\hline Sumy & 0.8355 & 0.5203 & 0.5113 & 0.7357 & 0.6507 \\
\hline Ternopil & 0.7109 & 0.5598 & 0.5458 & 0.7124 & 0.6322 \\
\hline Kharkiv & 0.7529 & 0.5847 & 0.6254 & 0.7455 & 0.6771 \\
\hline Kherson & 0.7856 & 0.5866 & 0.5083 & 0.7051 & 0.6464 \\
\hline $\begin{array}{l}\text { Khmelnytsk } \\
\text { yi }\end{array}$ & 0.6945 & 0.4914 & 0.4670 & 0.6493 & 0.5755 \\
\hline Cherkasy & 0.4276 & 0.3994 & 0.4325 & 0.6532 & 0.4782 \\
\hline Chernivtsi & 0.4963 & 0.4989 & 0.6023 & 0.6009 & 0.5496 \\
\hline Chernihiv & 0.8137 & 0.6327 & 0.4831 & 0.6284 & 0.6395 \\
\hline - & & & - medium & & \\
\hline
\end{tabular}

TABLE I. DIVISION OF UKRAINE REGIONS ACCORDING TO INTEGRAL INDICES OF SUSTAINABLE DEVELOPMENT SPHERES*

The regions of Ukraine are rated in accordance with indices of resource support, production, social development and ecology state on the average during 2010-2016 as follows: the first eight ones according to integral index are Ivano-Frankivsk, Cherkasy, Volyn, Kyiv, Zakarpattia, Lviv, 
Poltava and Chernivtsi regions; the lowest rating is obtained by Luhansk, Odesa, Donetsk, Zaporizhia, Kharkiv, Dnipropetrovsk, Mykolaiv and Kirovohrad regions.

These regions obtain comparatively high positions for the majority of indices in all directions, such as resource support, production, social development and ecology state. However, Ivano-Frankivsk and Zakarpattia regions have a low level of social development and Volyn region has alow level of production.

The comparison of integral indices of four index groups revealed some divergence in ratings.

Eight top regions in resource support are IvanoFrankivsk, Zakarpattia, Volyn, Cherkasy, Kyiv, Vinnytsia, Chernivtsi and Lviv regions.

Eight top regions in production are Ivano-Frankivsk, Poltava, Cherkasy, Lviv, Kirovohrad, Khmelnytskyi, Kyiv and Chernivtsi regions.

Eight top regions in social development are Cherkasy, Volyn, Zhytomyr, Mykolaiv, Khmelnytskyi, Vinnytsia, Poltava and Chernihiv regions.

There are outsider regions according to all indices Zaporizhia and Luhansk regions.

Eight top regions in ecology state are Volyn, Kyiv, Ivano-Frankivsk, Zakarpattia, Rivne, Zhytomyr, Lviv and Chernivtsi regions.

The analysis of all regions based on integral assessment concerning major statistics indices (Table II) affirms considerable homogeneity of regions within the context of sustainable development.

TABLE II. MAJOR STATISTICS INDICES OF UKRAINE REGIONS DIVISION BY SUSTAINABLE DEVELOPMENT SPHERES

\begin{tabular}{|l|l|l|l|l|l|}
\hline $\begin{array}{c}\text { Statistics } \\
\text { index }\end{array}$ & $\begin{array}{c}\text { Resource } \\
\text { support }\end{array}$ & Production & $\begin{array}{c}\text { Social } \\
\text { development }\end{array}$ & $\begin{array}{c}\text { Ecology } \\
\text { state }\end{array}$ & $\begin{array}{c}\text { Integral } \\
\text { assessment }\end{array}$ \\
\hline $\begin{array}{l}\text { Variation } \\
\text { scope }\end{array}$ & 0.772 & 0.582 & 0.250 & 0.454 & 0.411 \\
\hline $\begin{array}{l}\text { Mean } \\
\text { value }\end{array}$ & 0.652 & 0.562 & 0.542 & 0.648 & 0.601 \\
\hline $\begin{array}{l}\text { Average } \\
\text { lineal } \\
\text { deviation }\end{array}$ & 0.163 & 0.099 & 0.067 & 0.099 & 0.083 \\
\hline $\begin{array}{l}\text { Standard } \\
\text { deviation }\end{array}$ & 0.194 & 0.129 & 0.075 & 0.119 & 0.098 \\
\hline $\begin{array}{l}\text { Variation } \\
\text { coefficient }\end{array}$ & $29.76 \%$ & $23.00 \%$ & $13.79 \%$ & $18.30 \%$ & $16.27 \%$ \\
\hline
\end{tabular}

The biggest variation scope (the interval between maximum and minimal value) among the regions is observed under recourse support $(0.77)$. In the production group this index equals to 0.58 and ecology state group -0.454 . The least variation scope (oscillation amplitude) under social development group is 0.25 . Integral assessment has variation scope of 0.41 .

Average value of indices varies from 0.652 for resource support to 0.542 for social development. It equals to 0.648 for ecology state and to 0.562 for production. Average value of integral assessment is 0.601 .

The biggest average lineal deviation also refers to resource support and equals to 0.163. Average lineal deviation is less in production and ecology state groups and equals to 0.99 . The least average lineal deviation is for social development group and is equal to 0.067 .

Similar phenomenon is observed for standard deviation index. The biggest value is 0.194 for resource support, it is followed by production (0.129), ecology state (0.119) and social development (0.075). According to integral assessment standard deviation is equal to 0.098 .

Variation coefficient in every case is less than $30 \%$ which shows homogeneity of all groups and integral assessment. For resource support it equals to $29.76 \%$, production $-23.0 \%$, ecology state $-18.3 \%$ and social development $-13.79 \%$

Thus, it may be stated that major problems exist in resource support of sustainable development where there is the most substantial regional difference and the biggest mean value that is approximate to negative maximum. The least regional differences are observed in social development where the totality of regions behaves the most homogeneously.

There is a vital issue of interdependence among resource support, production, social development and ecology state.

The correlation matrix (Table III) demonstrates the fact that resource support is the most tightly connected to production indices (correlation coefficient is equal to 0.61 ) and ecology state (correlation coefficient is equal to 0.68). At the same time, social development and resource support virtually do not depend on each other (correlation coefficient is equal to - 0.02).

TABLE III. DIVISION OF UKRAINE REGIONS ACCORDING TO INTEGRAL INDICES OF REGIONS DEVELOPMENT

\begin{tabular}{|l|l|l|l|l|}
\hline $\begin{array}{c}\text { Indices group of } \\
\text { regions } \\
\text { development }\end{array}$ & $\begin{array}{c}\text { Resource } \\
\text { support }\end{array}$ & Production & $\begin{array}{c}\text { Social } \\
\text { development }\end{array}$ & $\begin{array}{c}\text { Ecology } \\
\text { state }\end{array}$ \\
\hline Resource support & 1 & 0.61 & -0.02 & 0.68 \\
\hline Production & 0.61 & 1 & 0.33 & 0.30 \\
\hline Social development & -0.02 & 0.33 & 1 & 0.13 \\
\hline Ecology state & 0.68 & 0.30 & 0.13 & 1 \\
\hline
\end{tabular}

The connection between production and social development is rather moderate (correlation coefficient is 0.33). The same happens to the connection between production and ecology state (correlation coefficient is 0.3 ).

The above mentioned calculations allowed us to define regions ratings for each index. In order to select objects under all indices groups, let's use the method of classification theory or cluster analysis which says that based on the given number of indices which are defined as major object features, every object of a general number belongs to the class it least differs from. The base of the classification algorithms is a function of distancing within the principle.

In order to conduct clustering the algorithm of k-means clustering was selected. The classification was made using Sigma system of statistics information processing developed in NSC "Institute of Agrarian Economic". The results of cluster analysis of Ukraine regions are given in Table IV. 
TABLE IV. The Results OF Cluster ANALYSIS OF UKRAINE REGIONS

\begin{tabular}{|l|l|l|l|l|l|c|}
\hline \multicolumn{1}{|c|}{ Region } & $\begin{array}{c}\text { Re- } \\
\text { source } \\
\text { sup- } \\
\text { port }\end{array}$ & $\begin{array}{c}\text { Produc- } \\
\text { tion }\end{array}$ & $\begin{array}{c}\text { Social } \\
\text { develop- } \\
\text { pment }\end{array}$ & $\begin{array}{c}\text { Ecolo- } \\
\text { gy } \\
\text { state }\end{array}$ & Distances & $\begin{array}{c}\text { Clu- } \\
\text { ster } \\
\#\end{array}$ \\
\hline Volyn & 0.420 & 0.641 & 0.448 & 0.407 & 0.234 & 1 \\
\hline Kyiv & 0.439 & 0.497 & 0.569 & 0.450 & 0.087 & 1 \\
\hline $\begin{array}{l}\text { Ivano- } \\
\text { Frankivsk }\end{array}$ & 0.176 & 0.214 & 0.609 & 0.466 & 0.348 & 1 \\
\hline Zakarpattia & 0.335 & 0.542 & 0.632 & 0.484 & 0.140 & 1 \\
\hline Lviv & 0.546 & 0.441 & 0.540 & 0.567 & 0.150 & 1 \\
\hline Chernivtsi & 0.496 & 0.499 & 0.602 & 0.601 & 0.139 & 1 \\
\hline Cherkasy & 0.428 & 0.399 & 0.433 & 0.653 & 0.189 & 1 \\
\hline $\begin{array}{l}\text { Average in } \\
\text { cluster 1 }\end{array}$ & $\mathbf{0 . 4 0 6}$ & $\mathbf{0 . 4 6 2}$ & $\mathbf{0 . 5 4 7}$ & $\mathbf{0 . 5 1 8}$ & $\mathbf{0 . 1 8 4}$ & \\
\hline Rivne & 0.599 & 0.641 & 0.500 & 0.502 & 0.180 & 2 \\
\hline Zhytomyr & 0.834 & 0.604 & 0.448 & 0.538 & 0.214 & 2 \\
\hline Poltava & 0.650 & 0.382 & 0.481 & 0.647 & 0.155 & 2 \\
\hline $\begin{array}{l}\text { Khmelnytsky } \\
\text { i }\end{array}$ & 0.695 & 0.491 & 0.467 & 0.649 & 0.061 & 2 \\
\hline Ternopil & 0.711 & 0.560 & 0.546 & 0.712 & 0.114 & 2 \\
\hline Vinnytsia & 0.470 & 0.537 & 0.471 & 0.754 & 0.226 & 2 \\
\hline $\begin{array}{l}\text { Average in } \\
\text { cluster 2 }\end{array}$ & $\mathbf{0 . 6 6 0}$ & $\mathbf{0 . 5 3 6}$ & $\mathbf{0 . 4 8 5}$ & $\mathbf{0 . 6 3 4}$ & $\mathbf{0 . 1 5 8}$ & \\
\hline Chernihiv & 0.814 & 0.633 & 0.483 & 0.628 & 0.141 & 3 \\
\hline Kherson & 0.786 & 0.587 & 0.508 & 0.705 & 0.091 & 3 \\
\hline Odesa & 0.825 & 0.796 & 0.627 & 0.711 & 0.169 & 3 \\
\hline $\begin{array}{l}\text { Dnipropetrov } \\
\text { sk }\end{array}$ & 0.684 & 0.661 & 0.619 & 0.722 & 0.132 & 3 \\
\hline Zaporizhia & 0.816 & 0.718 & 0.606 & 0.726 & 0.087 & 3 \\
\hline Sumy & 0.836 & 0.520 & 0.511 & 0.736 & 0.137 & 3 \\
\hline Luhansk & 0.949 & 0.770 & 0.653 & 0.740 & 0.211 & 3 \\
\hline Kharkiv & 0.753 & 0.585 & 0.625 & 0.746 & 0.094 & 3 \\
\hline Mykolaiv & 0.891 & 0.570 & 0.449 & 0.764 & 0.166 & 3 \\
\hline Donetsk & 0.687 & 0.735 & 0.683 & 0.785 & 0.194 & 3 \\
\hline Kirovohrad & 0.811 & 0.470 & 0.509 & 0.862 & 0.219 & 3 \\
\hline $\begin{array}{l}\text { Average in } \\
\text { cluster 3 }\end{array}$ & $\mathbf{0 . 8 0 5}$ & $\mathbf{0 . 6 4 0}$ & $\mathbf{0 . 5 7 0}$ & $\mathbf{0 . 7 3 9}$ & $\mathbf{0 . 1 4 9}$ & \\
\hline
\end{tabular}

Source: author's collaboration.

The results of cluster analysis are as follows: seven regions belong to Cluster 1 (Volyn, Kyiv, Ivano-Frankivsk, Zakarpattia, Lviv, Chernivtsi and Cherkasy), they possess the highest level of resource support, production and ecology state. But the social development level is lower on average than for the regions from Cluster 2. Cluster 3 consists of regions with the lowest level of all the directions under study. The regions division is reflected on the map (Figure 1).

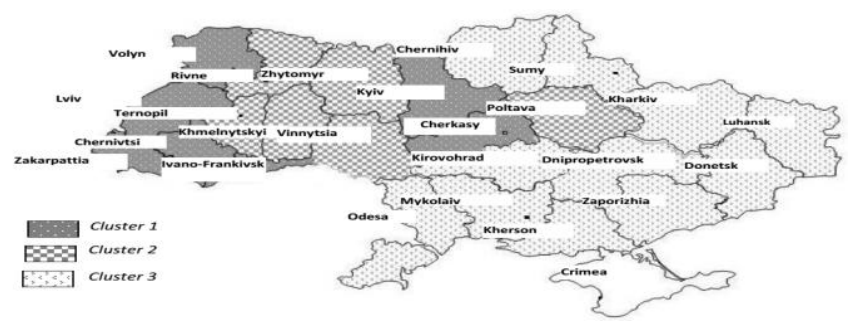

Source: author's collaboration.

Fig. 1. The results of cluster analysis of Ukraine regions

\section{CONCLUSIONS}

The analysis of regional peculiarities of providing sustainable development which was based on four indices groups (resource support, production, social development and ecology state) demonstrates the existence of regional differences that is fixed using the cluster analysis results. The statistics indices analysis shows considerable homogeneity of regions within the context of sustainable development and its particular spheres. Within limits of moderate differentiation the biggest disproportions are observed in resource support of sustainable development, and the most homogeneous one is social development sphere. But all the regions are similar considering the level of sustainable development providing being insufficient which requires using universal and inclusive tools for its implementation.

The analysis results may become a base for developing regional strategies of sustainable development for each region in Ukraine as well as for particular clusters. The implementation of new, active role of a region as a subject of sustainable development must become a strategic direction of regional policy development.

The conducted assessment of regional sustainable development and the established clusters enable directors of different levels of state power to define weak and strong sides of current regional policy and establish priority directions of their further activity. The results of the study demonstrate the necessity of differential approach to development of Ukraine regions and unified state strategy based on the sustainable development principles.

\section{REFERENCES}

[1] Agenda 21. United Nations Conference on Environment and Development. Rio de Janerio, Brazil, 3-14 June 1992. [Online]. Available: https://sustainabledevelopment.un.org/content/documents/ Agenda21.pdf. Accessed on: August 3, 2019

[2] Transforming our World: The 2030 Agenda for Sustainable Development A/RES/70/1. 2015. United Nations. [Online]. Available: https://sustainabledevelopment.un.org/content/documents/21252030\% 20Agenda\%20for\%20Sustainable\%20Development\%20web.pdf. Accessed on: August 3, 2019.

[3] At the conference in Buenos Aires the UN President reminded about major tasks for the humanity. [Online]. Available: https://news.un.org/ru/story/2019/03/1351431. Accessed on: August 18, 2019.

[4] M. Zhurovskyi, and V. Sadovnichii. Continuous and Distributed Systems II: Theory and Applications, Springer, 2015. [in Ukrainian].

[5] V. Heiets, "Development and interaction of economic and energy policy in Ukraine", Visnyk of the National Academy of Sciences of Ukraine, vol. 2, pp. 46-53, 2016 [in Ukrainian].

[6] M. Khvesyk, A. Shubalyi, and V. Golian, "Multicriteria evaluation of forestry development by regions (by the example of Ukraine)", Folia Forestalia Polonica, vol. 59, no. 3, pp. 207-218, 2017.

[7] Z. Herasymchuk, and A. Krysak, "Efficiency of financial and economic land relations regulation in forestry land resources use", Aktualni Problemy Ekonomiky = Actual Problems in Economics, no. 180, pp. 270-281, 2016. [in Ukrainian]

[8] About approval of the Method of calculating integral regional indices of economic development. State committee of Ukraine statistics. [Online]. Available: https://zakon.rada.gov.ua/rada/show/v011420203/sp:max15. Accessed on: August 14, 2019. [in Ukrainian]

[9] The regulation of the Cabinet of Ministers of Ukraine from October 21, 2015 № 856 “About approval of the Order and Method of monitoring and estimating effectiveness of state regional policy implementation". [in Ukrainian]. 